\title{
American Religion in the Era of Increasing Polarization
}

Forthcoming in Annual Review of Sociology

Samuel L. Perry ${ }^{1}$

\begin{abstract}
Americans are increasingly polarized by a variety of metrics. The dimensions, extent, causes, and consequences of that polarization have been the subject of much debate. Yet despite the centrality of religion to early discussions, the analytical focus on America's divides has largely shifted toward partisan identity, political ideology, race, and class interests. I show that religion remains powerfully implicated in all dimensions of American polarization, and sociologists must once again make religion more central to their analyses. After outlining research on American polarization, focusing on the role of religion, I survey findings within the burgeoning literatures on cultural transformation processes, (white) Christian nationalism, complex religion, and Americans' attitudes toward science in order to underscore the centrality of ethno-religious identities, religious demography, and religious institutions for both shaping and exacerbating various forms of polarization. Lastly, I propose an agenda for elucidating religion's ongoing role in understanding polarization beyond public opinion research at the macro-, meso-, and microlevels. Though polarization research has been dominated by political scientists, leveraging religion in our analyses - not merely as a sui generis "variable," but as a "site" of complex social behavior - facilitates novel sociological contributions to these literatures via our relative attention to multiple levels of analysis, theoretical eclecticism, and methodological fluidity.
\end{abstract}

Keywords: polarization, politics, culture war, Christian nationalism, race, complex religion, science

RECOMMENDED CITATION:

Perry, Samuel L. 2022. "American Religion in the Era of Increasing Polarization." Annual Review of Sociology. DOI: 10.1146/annurev-soc-031021-114239

${ }^{1}$ Department of Sociology, University of Oklahoma, Norman, Oklahoma 73019, USA 


\section{INTRODUCTION}

Americans are divided and increasingly so. To be sure, they are not divided in every regard. In fact, much of the talk of "culture wars" and "polarization" has been notoriously exaggerated given that Americans are consistently liberalizing and trending toward convergence on a number of important moral and social issues (Baldassarri \& Park 2020, DiMaggio et al. 1996, Hout 2021). Yet with that caveat in mind, countless studies now document that political elites continue to polarize toward extremes on civil rights, social, and moral issues (Fischer \& Mattson 2009, Liu \& Srivastava 2015, Vann 2021); the American public is increasingly sorting along partisan lines according to specific social characteristics (Baldassari \& Gelman 2008, Fiorina 2017, Fiorina \& Abrams 2008, Mason 2018); and as they sort, Americans are growing more hostile and distrustful toward members of social, political, and ideological out-groups (Finkel et al. 2020, Iyengar et al. 2019, Mason 2015, 2018).

Is this cause for worry? Some applaud certain aspects of polarization arguing, for example, that partisan sorting increases voter participation and engagement (Abramowitz \& Saunders 2008, Hetherington 2008), which is notoriously low in the United States among Western nations (Bolzendahl \& Coffe 2013). Others propose that sorting or "issue partisanship" could center actual policy positions rather than personalities in most elections. The idea being that citizens can more easily align themselves with parties and candidates who consistently represent their issue preferences (American Political Science Association 1950, Layman et al. 2006). However, others argue that even partisan sorting may bring more harm than good, and most conceive of extreme polarization — not only among parties, elites, and activists, but at the social and ideological level in the general public — as a concern for several reasons.

Gridlock and Collective Ineffectiveness: Polarization in terms of partisan sorting potentially inhibits political or mass cooperation to overcome common threats, or even to recognize such threats exist (Finkel et al. 2020, Lee 2015). The most obvious immediate issues for which there would ostensibly be strong motivation to transcend partisan, ideological, or social differences would be climate change and the COVID-19 pandemic. And yet, these issues have become powerfully polarizing, limiting the government's ability to respond or the public's willingness to adjust their social behavior (Johnson \& Schwadel 2019, McCright \& Dunlap 
2011, Perry, Whitehead, \& Grubbs 2020, 2021b, Whitehead \& Perry 2020a), resulting in immediate deaths and incalculable threats in the long term.

Social Capital: Related to this problem, polarization inhibits coordination and trust at the interactional level. For example, research increasingly shows that the growing alignment between partisan, ideological, and social identities produces "political sectarianism," characterized by in-group bias, partisan activism, and out-group anger (Finkel et al. 2020, Mason 2015, 2016, 2018). This "affective polarization" can also increase sorting further, such that persons self-select into situations and groups where they will only be around those with similar outlooks and lifestyles (DellaPosta et al. 2015, Margolis 2018, Rhodes 2011; Vaisey \& Lizardo 2010, but see Mummolo \& Nall 2017). Partisans are also more likely to consume media that affirms their biases (Finkel et al. 2020). And though the polarizing effects of social media are hotly debated (Prior 2013), recent findings suggest social media eco-chambers and the partisan media industry are intensifying affective polarization (Bail 2021, Schradie 2019).

Democratic Breakdown: Polarization also threatens American democracy. Pluralistic societies that maximize participation and integrate citizens are not without conflict. But conflict proceeds along multiple lines of group interest and identity (Baldassarri \& Gelman 2008, Wuthnow 2021). Cross-cutting interests inhibit the "stacking" of social identities into allencompassing "mega-identities" (Finkel et al. 2020, Mason 2018), while intergroup competition limits the power of single interest groups and promotes openness to democratic processes. Polarization, in contrast, represents a threat to democracy in that it organizes individuals and groups along common lines of conflict. This elevates the stakes in every political contest, increasing the likelihood that partisan elites will try to manipulate judiciaries, permanently handicap the opposition, or change laws to ensure victory (Levitsky \& Ziblatt 2018, see also Arbatli \& Rosenberg 2020, Hasen 2019, Mayrl \& Venny 2021). This could promote a crisis of legitimacy, paving the way for authoritarian populist movements to elevate the "lying demagogue" (Hahl et al. 2018).

Central to the earliest sociological analyses of elite and public opinion polarization around the mid-1990s were discussions of "culture wars" between religious conservatives who affirmed an objective, external authority and seculars or progressives who claimed their own moral authority (Davis \& Robinson 1996, DiMaggio et al. 1996, Hunter 1991, 1994). Though the idea of "culture war" has remained central to discussions of polarization (Bail 2021, Castle \& 
Stepp 2021, Baldassarri \& Park 2020), the prominence of religious identities, beliefs, and behaviors to these discussions has largely faded into the background (also pointed out by Grzymala-Buss's 2012 review). More explicit attention has been given to partisan identification and political ideology (by far) along with race and class background in their connection with polarization.

In this review, I argue why and how religion must once again be given a more prominent role in sociological analyses of polarization. Religion remains powerfully implicated in a bidirectional relationship with America's partisan and ethno-cultural divides at all levels of analysis: macro (laws, policies, elections, national identities), meso (institutions), and micro (everyday interactions and beliefs). Consequently, social scientists ignore or minimize religion in its various dimensions at the cost of a comprehensive understanding of America's most intractable contemporary conflicts. Moreover, as polarization scholars have recently called attention to the "religious" character of partisan politics (using language like "political sectarianism," see Finkel et al. 2020), religion need not necessarily be considered a sui generis "variable," but also a "site" to observe social dynamics that can be theoretically exported to understanding current political behaviors (Guhin 2014, see also Brubaker 2015).

The review is unavoidably selective. Though religion can certainly play a role in bridging America's divides and strengthening democracy (Putnam \& Campbell 2010, Wuthnow 2021), I focus more on religion as it corresponds with increasing social, ideological, and partisan cleavages. I also give greater attention to work that has been, or can be, more generative for furthering sociological theory on these topics. Though attention is given to relevant work by political scientists, this review will only scratch the surface of that discipline's exhaustive work on polarization (see helpful reviews in Fiorina \& Abrams 2008, Grzymala-Buss 2012, Hasen 2019, Iyengar et al. 2019, Layman et al. 2006, Lee 2015, McCarty 2019, Pierson \& Schickler 2020)

In in the following sections, I first outline research on polarization in the United States, focusing especially on how religious factors have been treated within that literature. I then survey the burgeoning research on cultural transformation processes, (white) Christian nationalism, complex religion, and Americans' attitudes toward science, in order to elucidate the centrality of ethno-religious identities, religious institutions, and religious demography for both further shaping and entrenching the widening divisions. I conclude by proposing an agenda for 
elucidating religion's role in Americans' increasing ethno-cultural and partisan divides beyond survey research, at the macro-, meso-, and micro-levels.

\section{RELIGION AND POLARIZATION RESEARCH}

Americans have always been divided along various social identities - including most obviously race and religion (Du Bois 1990 (1903), Herberg 1955). Yet social scientists did not turn their attention to the idea of mass "polarization" in earnest until the late 1980s. In his classic article, Converse (1964) documented that, unlike political elites, most Americans in that era were unsophisticated in their political views, unclear about the differences between "liberals" and "conservatives," and their stances on various issues were not strongly correlated with one another (see the famous complaints in American Political Science Association 1950).

Much of the early empirical debate regarding polarization was in response to claims of a growing “culture war” dividing Americans. Even before Pat Buchanan's famous speech at the 1992 Republican National Convention rallying conservatives to a "religious war...for the soul of America," Wuthnow $(1988,1989)$ argued that Christians communities were "fragmenting" and "restructuring" as denominational affiliations weakened and Americans realigned into "religious conservatives" who were conservative about both religion and politics and "religious liberals" who were more liberal on both. This was a consequence, Wuthnow argued, of expanding higher education, Civil Rights, proliferating special purpose organizations, and weakening denominational identities. Taking these arguments a step further, Hunter $(1991,1994)$ articulated a "culture war" thesis pitting religiously orthodox conservatives who affirm external and transcendent moral authority against cultural progressives who embrace a more relativistic approach to authority and include religious liberals and seculars. As the ominous title of Hunter's 1994 book Before the Shooting Starts suggests, this growing divide represented a grave threat to democracy.

But was this so-called "war" among Americans in general or the elite primarily? As Evans (2003, p. 88) points out, Hunter was inconsistent. On the one hand, Hunter $(1991,1994)$ used national survey data to document polarization and claimed, "The culture war encompasses all Americans" (Hunter 1991, p. 46). Yet later he clarified "the culture war of which I speak cannot be explained in terms of ordinary's people's attitudes about public issues" (Hunter 1994, 
p. vii, Evans 2003, Uecker \& Lucke 2011). Rather "culture war," in his view, represented competing moral visions that could be reflected in public opinion, but result from their being institutionalized.

Hunter's supposed argument that the American public was gravely fractured helped motivate an explosion of research examining the extent to which Americans had indeed grown more ideologically divided. DiMaggio et al. (1996) provided a seminal study of polarization, defining its dimensions, identifying methods to assess their existence or extent, and testing hypotheses using national data (see also Alwin \& Tufis 2016, Lelkes 2016, Levendusky \& Pope 2011). Ultimately, DiMaggio et al. (1996) documented that claims of an increasingly polarized public were unsubstantiated, except for the abortion issue. However, they also found that social attitudes were consolidating around partisan identities, reflecting the pattern of extreme partisan sorting that has only grown in recent decades. Using a rather arbitrary and crude measure of "religious conservatives" (evangelicals or Catholics who attend church almost weekly or more) versus "religious liberals" (mainline Protestants, Jews, and the unaffiliated), they actually found that the social attitudes of religious conservatives and liberals had converged during the 1970s and 1990s. The exception was the issue of prayer and Bible-reading in public schools, for which there was persistent divergence (also Evans 2003). Davis \& Robinson (1996) also debunked the neat "culture war" dichotomy using 1991 General Social Survey (GSS) data. Not only did Americans converge around moderate positions on most issues, but the religiously "orthodox" were more conservative than religious progressives on gender roles and reproductive rights, no different on racial inequality, and actually more liberal on government safety nets. This suggested religious conservatives at the time where pulled in opposite directions, rightward on social relationships and moral issues, but leftward on economic issues, partially because religious conservatives were comprised of more working-class Americans.

Providing a more fine-grained look at polarization between religious groups, Hoffmann \& Miller $(1997,1998)$ showed religious groups were largely converging on issues of women's roles, but Americans in conservative Protestant denominations were increasingly diverging from other religious groups on the issue of public school prayer and Bible reading. And in a later updating of DiMaggio et al.'s (1996) analysis by Evans (2003, p. 87), more recent data confirmed that partisans were increasingly sorting "over the issues that have been of concern to politically active religious conservatives" (e.g., abortion, divorce law, sexuality, school prayer, 
etc.), though not necessarily polarizing religious conservatives from religious liberals. This suggested divides were growing principally among those who merged religious identity and partisanship.

Despite persistent findings that social attitudes had not polarized among the general public, the growing phenomenon of partisan sorting among more religious Americans became inarguable. Manza \& Brooks (1997) documented that, though religious identity had little influence on voter choice or political engagement itself, religious cleavages in presidential vote choice were increasingly driven by partisan realignments among liberal Protestants, evangelicals, and Catholics. And looking at voting behavior, Abramowitz \& Saunders (2008) found that among white voters, "religiosity" (measured with frequent church attendance and evangelical affiliation) was a stronger predictor of vote choice in 2004 than any other characteristic, including class or age. Religious conservatism and religiosity have since become even more reliable indicators of partisanship and participation (Campbell et al. 2021) and Schwadel's (2017) analysis of 1973-2012 GSS data affirms this connection was largely the result of issue alignment between religious conservatives and the Republican party. Yet despite these sorting patterns, partisan and religious identities remain distinct enough to demonstrate independent influences on political attitudes, particularly on sex, gender, abortion, and church-state separation (Castle \& Stepp 2021).

Though partisan realignment has largely proceeded as Americans with stable religious dispositions and identities have sorted along ideological and partisan lines (Davis 2018), several studies argue that partisanship and political ideology have become such central organizing identities that they are driving religious identities and behaviors (Campbell et al. 2021, Margolis 2018, Patrikios 2008). Pioneering this argument, Hout \& Fischer (2002, 2014) documented that, in addition to generational replacement, the increase in Americans claiming "no religious preference" was largely a consequence of political conflicts. Unaffiliated Americans were not abandoning orthodox beliefs, but rather the increase in "no religion" was confined to political moderates and liberals who were likely reacting to the growing alignment of Christian identity with the Religious Right and Republicans. Thus we see an instance of politics and political identity influencing religion (see also Patrikios 2008). Hout \& Fischer subsequently (2014) updated their analyses with panel data and found that the causal direction for the rise of the unaffiliated ran from political to religious identity for both liberals and conservatives, thus 
indicating that partisanship and political ideology are bolstering both religious and secular identities (Campbell et al. 2021, Margolis 2018). Moreover, Gullickson's (2018) analysis of updated GSS data indicates that the "unaffiliated" began abandoning orthodox religious beliefs and practices after 2000, suggesting that more secular identities increasingly associated with non-Republican partisanship were adopting corresponding secular beliefs and lifestyles.

Despite the profound partisan sorting or "issue partisanship" of Americans, data have not substantiated radicalized or even bimodal patterns in Americans' social attitudes (Baldassarri \& Park 2020, Park 2018, but see Castle \& Stepp 2021). Yet despite the convergence of Americans on a large number of social issues, studies increasingly document a link between partisan sorting and affective polarization. The latter aspect of polarization has been explored considerably within the past decade, drawing on insights from evolutionary psychology and social identity theory (Brewer \& Pierce 2005, Iyengar et al. 2019). In numerous studies, Mason (2015, 2016, 2018) demonstrates that "social sorting" along partisan lines (in which various social identities are stacked to produce "mega-identities") reinforces in-group bias and out-group animosity. Though she does not interpret the religious findings, her (2015) analyses document that evangelical identity independently increases bias against the opposing political party, while church attendance is a positive predictor of political activism.

Newer research also affirms the partisan sorting of religious groups becomes a "selffulfilling prophesy," as religious identity functionally merges with partisan or ideological identity. For example, Rhodes (2011) found that evangelical Democrats were less likely to attend church, all else being equal, likely because they felt out of step with the majority of their coreligionists, thus reinforcing the idea of a secular Democratic party. Similarly, Mason \& Wronski (2018) demonstrate that religious identities like "Christian" and "Atheist" now intensify partisanship, such that Christian Republicans are stronger partisans than Christian Democrats and Atheist Democrats are stronger partisans than Atheist Republicans. And Claassen et al. (2021) shows that evangelicals are more likely to overestimate the evangelical composition of the Republican party and the secular composition of the Democratic party, suggesting Americans are sorting into parties not solely on issues, but following popular conceptions of where "people like me" belong.

Though studies continue to document the tight connection between religious factors and various indicators of partisanship, political ideology, or affective polarization, they are seldom 
the explicit focus of attention in most polarization research. In the political science and sociology literature, partisanship and political ideology are now understood to either drive sorting or even drive religious identity (see Brooks \& Manza 2013, Campbell et al. 2021, Lelkes 2016, Margolis 2018, Mason 2018), while others highlight the roles of ethno-racial (Abramowitz \& McCoy 2018, Alba \& Foner 2017, Hout \& Maggio 2021, McVeigh et al. 2014, Oberhauser et al. 2019) or class dynamics (including income and education) (Alwin \& Tufis 2016, Fischer \& Mattson 2009) in polarization patterns.

One of the relative advantages sociologists can bring to the study of polarization in all its dimensions is our flourishing theoretical eclecticism. Complex subjects demand multiple perspectives at different levels of analysis. Thus, in the following section I survey burgeoning research in several diverse areas that can be leveraged to refocus attention on religion's role within sociological analyses of America's ethno-cultural and political divides. These areas are of course selective, yet already yielding promising insights and possibilities.

\section{AVENUES TO LEVERAGE RELIGION IN POLARIZATION RESEARCH}

\section{Cultural Transformation Processes}

Central to the polarization discussion has historically been the idea of "culture war" or fragmentation, and thus required tracking how various attitudes, beliefs, identities, and values change across generations and within generations. Though often disconnected from polarization research, analyses of cultural change can shed tremendous light on the dynamics of political and social conflict and their interplay with religion. In their comparative analysis of cultural change, Inglehart \& Baker (2000, see also Grzymala-Buss 2012) documented that societal values often evolve with economic development, from absolutist to more rational and tolerant. But the changes are path-dependent, largely on the religious heritage of a society (e.g., Protestant, Catholic, Confucian), which shape the axis along which societies will polarize and the terms of disagreements. I will return to this idea when I discuss white Christian nationalism.

Closely linked with the study of (religious) values have been innovative sociological examinations of dual process cognition and the deeply-embedded nature of social values. Vaisey \& Lizardo (2010) documented that inculcated "moral-cultural worldviews" (derived from Hunter 
2000) were more likely to determine young Americans' friendship networks rather than the reverse. More recently Vaisey \& Kiley (2021, also Kiley \& Vaisey 2020) provided strong evidence that attitudes among individuals are largely stable over time and thus cultural changes primarily take place as younger cohorts replace older cohorts rather than individuals updating their views with new information. These findings have significant implications for polarization research. The finding that worldviews influence network composition would reinforce the notion that strong partisans and those who hold their worldviews intensely would be more likely to associate with like-minded persons and thus reinforce the echo-chamber. And the fact that social attitudes reveal somewhat settled dispositions and thus cultural change happens largely via cohort replacement demands that scholars understand demographic transition to analyze cultural and political conflict.

How do these findings help make religion a more primary focus in polarization analyses? Central to previous discussions of religion within the polarization literature are the divide between religious conservatives and liberal or secular Americans. But it is less often recognized that these are changing in their political engagement. To what extent is "engagement" with politics becoming a stable disposition or aspect of cultural identity that itself guides the selfselection and sorting process? Numerically, white religious conservatives and the intensely religious seem to be holding steady (Schnabel \& Bock 2017, but see Voas \& Chaves 2018), while white religious moderates and liberals are both aging and plummeting numerically. The latter is also declining in their political engagement. Despite increasing interest in religion and progressive politics (Braunstein et al. 2017), Baker \& Marti (2020) document that Americans who self-identify as both religious and politically liberal have steadily disengaged from political activity in the past decade. On the contrary, it is secular liberals who have become the most politically engaged within the past few election cycles. Moreover, secular Americans have been the fastest growing religious category, with "nones" virtually equaling evangelicals in their proportion of the population (Burge 2021). Drawing from Vaisey \& colleagues (Vaisey \& Kiley 2021, Vaisey \& Lizardo 2010) we could expect a growing disposition toward political engagement, as politically engaged Americans seek out likeminded activists and replace older disengaged cohorts. But following population trends, this disposition would be sorted into Religious Right and Secular Left, replacing moderately religious, disengaged Americans (see Abramowitz 2010). Conflict could intensify, in other words. 
Yet the "secularization" of Americans" religious identities and social attitudes is happening within generations as well as across generations. In their analysis of polarization trends, Baldassari \& Park (2020) document that while Democrats and Republicans are polarizing on civil rights and economic issues, there is general "secularization trend" on moral issues that tends toward convergence (see also Hout 2021). Though the secularization trend happens more rapidly for Democrats than Republicans, Republicans are trending in the same direction (see this pattern for evangelicals in Schnabel 2016). The authors do not connect "secularization" with religion. Yet the language is apt as moral attitudes in the general public become less connected to "traditional" religious proscriptions for both liberals and conservatives (eventually). Baldassarri $\&$ Park (2020) point out that these trends are happening too rapidly to be the result of demographic replacement alone. Thus they theorize that such changes can be catalyzed at the interactional level by more progressive conversation partners who encourage one another to adopt more progressive views (see also Baldassari \& Bearman 2007).

This interactionist notion of value modification fits with the self-selecting network arguments proffered by Vaisey \& Lizardo (2010), but the latter's theory of cultural change (Vaisey \& Kiley 2021, Kiley \& Vaisey 2020) suggests these self-reinforcing interactions in combination with cohort replacement could lead to intense polarization between deeply engaged religious and secular Americans on civil rights and economic issues. Supporting this notion, Vogl \& Freese (2020) document that the higher fertility of religious conservatives demonstrably exacerbates polarization as Americans in general become more liberal, but religious conservatives resist liberalizing trends on a battery of moral and civil rights issues, while growing in number. Thus leveraging insights from research on the dominant pathways through which culture is transformed, we are forced to confront the power of religious (or irreligious) identities, networks, and demographic patterns for understanding how those processes are unfolding.

\section{(White) Christian Nationalism}

The "civil religion" concept has repeatedly appeared in polarization research. Bellah (1967) famously framed "American Civil Religion" as a unifying, transcendent understanding of American purpose and identity. In contrast, Christian nationalism refers more to an ideology that 
sectarian Christianity should exercise greater influence in America's elections, public policies, sacred symbols, and self-understanding (Gorski 2017, Gorski \& Perry 2022, Whitehead \& Perry 2020a). Though long part of American political discourse, sociologists and political scientists have only recently begun to conceptualize, measure, and operationalize the influence of Christian nationalist ideology on Americans' social attitudes, voting behavior, and democratic institutions (Gorski \& Perry 2022, McDaniel et al. 2011, Whitehead et al. 2018).

Yet we see hints of Christian nationalism driving partisan sorting in earlier decades. Both DiMaggio et al. (1996) and Evans (2003) found that "religious conservatives" and "religious liberals" consistently diverged in their attitudes toward the Supreme Court decision that banned teacher led prayer and Bible reading in public schools, reflecting a persistent rift in the American public on religion's place in public institutions. This debate represents a religion-directed path along which American polarization takes place (Inglehart \& Baker 2000), namely, the institutionalization of sectarian Christianity in the public sphere (Smith 1998), and the socialization of children. Analyses of the GSS from 1974-2018 (not shown) reveal that while Americans are slowly growing colder to the idea of prayer and Bible reading in public schools, strong Democrats and strong Republicans have indeed been polarizing on this issues since the mid-1980s. And though not directly addressing Christian nationalism, Castle \& Stepp (2021) document significant partisan and religious polarization on the issue of church-state separation.

Later studies looking at different data sources from the mid-1990s to mid-2000s found that the more Americans connect Christianity with American civic life, the more likely they were to be intolerant of religious and ethnic minorities, unfavorable toward welfare spending, and hawkish on foreign policy (Davis 2018, 2019, Edgell \& Tranby 2010, Froese \& Mencken 2009). Addressing the "culture war" thesis directly with data from the 2003 American Mosaic Project, Edgell \& Tranby (2010) propose that "cultural preservationists" (who see American society as unified around whiteness and Christianity) believe they are indeed at war, with encroachments from ethnic and religious outsiders eroding the cultural core. Importantly, they also found cultural preservationists are more likely than others to be religiously active and identify as Republican and conservative Protestant.

Also using data from the mid-2000s, political scientists (McDaniel et al. 2011) and sociologists (Perry \& Whitehead 2015, Whitehead \& Perry 2015) analyzed Christian nationalism leveraging insights from social identity theory that would later become so central within 
contemporary research on affective polarization (Iyengar et al. 2019, Mason 2015, 2018). Building on social identity complexity theory in particular, scholars argued that Americans who conflated religious and national identities (and in the case of whites, racial identities as well) had lower identity complexity and thus would be more intolerant of ethnic or moral outsiders. These findings were bore out as Christian nationalist ideology was powerfully connected to intolerance toward religious or ethnic outsiders, same-sex unions, and transgender rights (McDaniel et al. 2011; Perry \& Whitehead 2015; Sherkat \& Lehman 2018, Stewart et al. 2018; Whitehead \& Perry 2015, 2020b).

Leading up to the 2016 election, Donald Trump leveraged affective polarization and negative partisanship, campaigning simultaneously on Islamophobia, xenophobia, and the promise of winning the country back for conservative Christians (Braunstein 2018, Edgell 2017, Gorski 2017). Subsequent studies found that Christian nationalism was among the most powerful predictors - behind political ideology and partisanship — that Americans voted for Trump in 2016 (Whitehead et al. 2018) and planned on voting for him in 2020 (Baker et al. 2020a). It is also among the most powerful predictors that white Americans in particular believe the 2020 election was stolen from Donald Trump and that he had nothing to do with the attempted insurrection at the US Capitol Building on January 6, 2021 (Gorski \& Perry 2022). In other words, white Christian nationalism lies at the center of American disagreement over one of the most polarizing presidencies and events in recent history.

Central to Christian nationalism's importance in understanding increasing polarization in the United States is that it appears to operate independently from traditional measures of partisanship, ideology, or religious characteristics. Though the vast majority of white evangelicals affirm Christian nationalist ideology, it can also be found among non-evangelicals, and even non-Christians (Delehanty et al. 2019, Gorski \& Perry 2022, Whitehead \& Perry 2020a). Moreover, its effects on various social attitudes typically surpass partisan identity and often equal or surpass those of conservative political ideology on certain outcomes (Baker et al. 2020b, Davis 2018, 2019, Davis \& Perry 2021, Perry, Whitehead, \& Grubbs 2020; 2021a, 2021b, Stewart et al. 2018, Whitehead \& Perry 2020a).

Moreover, recent work shows Christian nationalist ideology is most powerfully connected with America's cultural and social divides among white Americans. Comparing Black and white Americans, for example, Christian nationalism does not seem to strongly influence the 
racial or social attitudes of the former as it does for the latter (Gorski \& Perry 2022, Perry, Whitehead, \& Grubbs 2021a, Perry \& Whitehead 2019). It is also connected with economic libertarianism, again, primarily among white Americans and documented right-wing libertarian groups like the Tea Party (Braunstein \& Taylor 2017, Gorski \& Perry 2022, Marti 2020, Perry, Whitehead, \& Grubbs 2021b). This racialized understanding of Christian nationalism puts the concept into conversation with other forms of ethno-nationalism (Bonikowski \& DiMaggio 2016) which have recently been shown to increase partisan sorting in the electorate and contributed to Trump's victory in 2016 (Bonikowski et al. 2019). These findings together suggest that Christian nationalist ideology represents a unique manifestation of ethno-cultural conflict that involves partisan, ideological, racial, and economic polarization, but must be examined in combination with them.

\section{Complex Religion}

Building on theoretical insights from the "complex inequality" and "intersectionality" literatures, a growing number of sociologists propose that scholars must take seriously the profound connectedness of American religion with race and class, among other forms of inequality (Edgell 2017, Wilde 2018, Yukich \& Edgell 2020). Wilde \& her co-authors (Wilde 2018, Wilde \& Glassman 2016, Wilde \& Tevington 2017, see also Braunstein 2021, Pearce \& Gilliland 2020, Chap. 2, O'Brien \& Abdelhadi 2020) have called this approach “complex religion.” The theory's fundamental insight is that religion so deeply intersects with ethno-racial identity and class background in the United States that a straightforward "variable" approach will often miss critical patterns of divergence across critical ethno-religious combinations or other configurations of religion with structural position. Though not remotely the first to document how religious and racial identities interact to differentially shape Americans' political attitudes and behaviors (e.g., Edgell \& Tranby 2007, Emerson \& Smith 2000, McDaniel \& Ellison 2008), the "complex religion" agenda represents a definitive push for scholars to take seriously these intersections in analyses going forward.

In an early articulation of the theory, Wilde \& Glassman (2016) argue that the unclear relationship between religious participation and political engagement or partisanship is the result of ignoring the role of inequality in religious affiliation or non-affiliation. Likewise, they contend 
social scientists fail to recognize the close connections between religion, class, and race. For example, they propose any analysis of religion in American politics and polarization must start with the understanding that religious communities are highly segregated by race and often by class. Though not applying the complex religion approach by name, Schnabel (2021) applied its insights in analyzing the interplay between religion, structural disadvantage, and politics. Providing nuanced support for Marx's "opiate of the masses" analogy, Schnabel found historically disadvantaged groups (e.g., Blacks, women, Latinos, and low-income Americans) use religion as a compensator and that this suppressed what would otherwise be more liberal political views and Democratic partisan voting.

Explicitly applying the complex religion theory to understanding polarization, O'Brien \& Abdelhadi (2020) trace partisan alignments across ethno-religious traditions and identities. Revisiting Wuthnow's (1988) “religious restructuring" argument, they clarify that partisan realignments among religious Americans are specific to white Americans. Though religious and political conservatism remain tightly linked for white Christians and Jews, doctrinal conservatism is unassociated with political conservatism for Black Protestants, Muslims, or Latino Catholics. Thus, growing partisan alignments are increasingly likely to be made of nonwhite religious conservatives and seculars on the left, and white religious conservatives on the right, with white religious liberals continuing to diminish in number. As O'Brien \& Abdelhadi's (2020)'s analysis suggests, another benefit of the complex religion approach is its potential for factoring in minority religious status as well as ethnic or class inequality. For example, Nojan (2021) uses undergraduate survey data to show that young Muslims, by virtue of their unique faith and collective experiences of religious and ethnic minority status, report higher levels of civic participation than other religious or irreligious groups. This is an important insight given Muslims and other non-white religious minorities represent a growing proportion of the voting public.

Braunstein (2021, also O’Brien \& Abdelhadi 2020) importantly integrates a complex religion approach with research on white Christian nationalism to argue that religious conservatives are themselves growing fractured by competing and racialized narratives of national history and identity. In the "white Christian nation" narrative, "whiteness, Christianity, and American patriotism are explicitly fused, and Christianity is used to legitimize a vision of American society rooted in white supremacy" $(2021$, p. 10). Those who deploy the "colorblind 
Judeo-Christian nation" narrative, in contrast, emphasize "the country's 'Judeo-Christian' heritage and either ignore race or use colorblind language to describe ideal Americans." Importantly, she documents that an increasing number of religious conservatives now strategically repeat the "colorblind Judeo-Christian nation" narrative in order to suppress the explicitly racialized goals of the current conservative movement.

\section{Americans' Attitudes toward Science}

Though scholars have often documented a growing liberal-conservative divide in their attitudes toward science, often these literatures center either partisanship or political ideology driving divergent attitudes (Gauchat 2012, 2015, Kozlowski 2021, Nisbet et al. 2015) or they focus on conservative religious identities and beliefs (O’Brien \& Noy 2015). Yet in this, there is a missed opportunity to further elucidate how religious identities and beliefs are implicated in possible epistemological power struggles between Americans. That is to say, the interaction between community understandings of science and religion, between sources of epistemological and moral authority (Baker et al. 2020b, Evans 2013, Hout \& Fischer 2014), help us understand the nature and depth of polarization.

Science has always been political because the cultural authority of science links society's definitions of knowledge and political authority (Gauchat 2012). The extent to which Americans distrust science or scientists for information is the extent to which they must turn to other sources of epistemological authority, among them being sacred texts, community traditions, charismatic religious leaders, or political demagogues (Cofnas et al. 2018, Gorski \& Perry 2022, O’Brien \& Noy 2015). As religious and ideological identities began to realign with partisan identities, both Republican partisanship and political conservatism corresponded to declining trust in scientists (Gauchat 2012, Kozlowski 2021) and support for spending on science or environmental protection (Gauchat 2015, Johnson \& Schwadel 2017). Why has this become the case? O'Brien $\&$ Noy (2020) document that confidence in science and religion reversed among Democrats and Republicans between 1973 and 2018, suggesting that the politicization of both science and religion pitted them against one another as representing socially and ideologically opposing camps. 
Among the recent attempts to examine the interplay between religion, science, and political polarization, Noy \& O'Brien (2016, see also O'Brien \& Noy 2015) document that individuals who are oriented to either religion or science differ on a host of social, political, and economic attitudes included in the GSS. Americans they call "moderns" (favoring science over religion) are liberal and inclusive, while "traditionals" (favoring religion over science) are conservative and exclusive. However, Americans who blend support for science and religion in their worldviews, whom the authors call "post-secular," are unique in their attitudes and do not map squarely onto the traditional liberal-conservative spectrum. Much like evangelical Protestants before thorough political sorting (Davis \& Robinson 1996, Smith 1998), postseculars' attitudes toward gender and sexuality are like "traditionals." But in their attitudes toward social safety nets, criminal justice, and government spending, post-seculars are like "moderns." And in their beliefs about school prayer and affirmative action, post-seculars stand apart. Importantly, these differences emerge despite accounting for partisanship, religious traditions, or political ideologies, suggesting orientations to religion and science contribute something unique to our understanding of polarization.

And recent studies on contentious moral issues suggests that "science" as a concept may itself be deployed by different interest groups in the cause of promoting policy changes. Burke \& MillerMacPhee (2021), for example, document that there is little scientific consensus around the "effects" of pornography viewing. Yet conservative interest groups - many of them religiousare nonetheless leveraging the cultural authority of "addiction" language in order to promote anti-pornography referenda and even potential pornography bans. In this same vein, Perry (2021) documents that the association between religious conservatism and support for anti-pornography legislation is tightening over time, just as the association between confidence in scientists and pornography bans is disappearing. This suggests that support for political action against pornography among the general public is "desecularizing," becoming more connected to religious belief, while wielding "science" as a political lever.

This tension between religious conservatism, selective belief in "science," and political views suggests a disjuncture between what many Americans perceive to be socially beneficial and objective "science" and the sort of liberalizing, debunking agenda conservatives associate with "scientists." The conservative disagreement, which often manifests itself as ignorance toward science (Evans 2013, Perry, Baker, \& Grubbs 2021) is in fact a rejection of objectionable 
scientific claims that stand against deeply held worldviews. Often these are manifested in negative attitudes toward "scientists" themselves (e.g., Baker et al. 2020b). Affirming this, Mann \& Schleifer (2021) documented that while conservatives' confidence in scientists has declined, their confidence in science's overall benefits to society remain stable. Similarly, weekly churchgoers' confidence in science's benefits remains far higher than their confidence in scientists themselves. This suggests that the politicization of science is related to affective polarization toward scientists and their perceived leftist opposition to religion or conservative moral values (Cofnas et al. 2018).

The politicization of the COVID-19 pandemic - including debates over the medical efficacy of masks, vaccines, and vaccine mandates - and its powerful association with religious conservatism underscores the centrality of religion for understanding increasingly polarized debates over scientific expertise (e.g., see Evans \& Hargittai 2020, Perry et al. 2020, Whitehead \& Perry 2020).

\section{RELIGION AND POLARIZATION: MACRO, MESO, AND MICRO}

Beyond deploying multiple theoretical angles to study religion's ongoing bidirectional relationship with America's increasing partisan, ideological, and social divides, I propose religion be made a more central focus in discussions at all levels of analysis. Sociologists are uniquely well-positioned to leverage religious phenomena here due to our relative methodological fluidity. Below I briefly outline some obvious opportunities that go beyond the traditional analyses of public opinion trends.

\section{Macro-level}

Religion unites all levels of political analysis, but continues to influence the macro in a variety of areas including elections and political elites, policies and laws, judicial appointments, and national identity, among others (Grzymala-Buss 2012). Measures of ethno-religious identity and commitment remain powerful predictors of voting behavior and choice, beyond the effects of political ideology and partisan identification (Whitehead et al. 2018). Yet this also works in the aggregate on elite behavior. Liu \& Srivastava (2015) document that the relative religiosity of 
U.S. Senator's constituents has a powerful influence on whether their chamber interactions with opposition-party Senators lead to greater or less polarized voting behaviors. And as Vann (2021) demonstrates, when vulnerable political elites in Republican contexts feel the influence of ethnoreligious identity politics on voting and donations, the result is more extreme partisan policy and electioneering. Indeed, the partisan sorting and affective polarization of the American public, combined with anxieties about the diminished status of white conservative Christians, made way for the anti-establishment Trump to win the GOP nomination and the 2016 election. Among the religious rationales given for supporting Trump among former "values voters" was assumptions about Supreme Court appointments and Trump's promises to defend "religious liberty" (Perry, Schnabel, \& Grubbs 2021). Trump responded by signing executive orders crippling the Johnson Amendment, bolstering religious exemptions to Obamacare's contraception mandate, and crippling anti-discrimination laws preventing federal contractors from discriminating in hiring. He also appointed three conservative justices highly favored among his conservative religious base.

Conservative religious Americans - and in particular, those who seek to ensconce racialized sectarian Christianity within U.S. national identity and policies - have also been among the leading advocates for the electoral college that privileges white rural Americans, gerrymandering which currently advantages Republicans throughout the country, and for various forms of voter suppression that could potentially preserve electoral victories (Gorski \& Perry 2022). Though white Christian nationalism has been the subject of much research at the individual level using national survey data, Trump's presidency and subsequent Trumpist movement within the Republican Party underscores the need for social scientists to consider white Christian nationalism as a "discursive style" and "political strategy" similar to analyses of populism's various dimensions (Gidron \& Bonikowski 2013).

The strategic gains of white conservative Christian coalitions at the electoral and judicial levels - that effectively structure sectarian Christian bias into policy-hold tremendous implications for increasing polarization given (1) the majority of Americans are moving toward greater tolerance of religious, racial, and sexual minorities (Baldassari \& Park 2020, Hout 2021) and (2) the number of white Christians is shrinking as the number of minority and secular Americans is growing (Burge 2020, Campbell et al. 2021). The foreseeable result is that political elites, many of whom were elected despite their parties receiving fewer votes in their state or 
nation (due to gerrymandering and the electoral college) who represent a shrinking number of Americans (older, white, conservative Christians) will increasingly set policies unfavorable to a growing population of minorities and secular Americans and will be supported by hand-picked federal courts favorable to religious conservatives. In other words, the result is moving toward a Herrenvolk democracy (Gorski \& Perry 2022). Sociologists cannot understand these macro-level changes without understanding the ethno-religious/secular dynamics.

\section{Meso-level}

Institutional analyses provide an opportunity to examine religion's role in further driving polarization at the meso-level (Pierson \& Schickler 2020). One example of this approach is Mayrl's (2018, see also Hasen 2019) analysis of the "judicialization" of religious freedom. Mayrl (2018) points out that (1) courts are both increasingly deciding religious matters and (2) the legal definition of religious freedom is expanding. While there are broad institutional reasons for the former trend, the latter has largely been the result of what Lewis (2017) calls "the rights turn" in conservative Christian politics. As society liberalizes on most moral issues at a faster pace than religious conservatives, the latter is forced to appeal to "religious liberty" in order to preserve their ability to oppose abortion, homosexuality, and transgender rights, and recently, to oppose mandates to wear masks, get COVID-19 vaccines, or stop in-person religious gatherings (Gorski \& Perry 2022, Perry, Schnabel, \& Grubbs 2021, Perry, Whitehead, \& Grubbs 2021a, 2021b).

As Mayrl points out, courts are not independent actors, but exist within an ecosystem with other political institutions or "venues" that can influence, cooperate with, or resist judicial efforts to shape law on religious matters. In the case of "religious freedom" issues, the Republican Party has exercised a growing influence on the federal courts from both the executive and legislative branches, changing their composition in order to consistently render decisions that will appeal to their constituencies. As pointed out in the previous section, influencing court appointments was among the primary reasons religious conservatives provided for supporting Donald Trump, and it was a campaign promise he fulfilled.

More recently, however, Mayrl \& Venny (2021) propose that the ideal political conditions may be emerging to witness a "dejudicialization" of religious freedom. As populist and ethno-nationalist movements gain steam throughout the world, it destabilizes democracy and 
weakens institutional supports for courts and the rule of law more broadly. There are numerous other institutions to consider, including educational systems (e.g., school curricula) and major denominations (e.g., cultural clashes within the Southern Baptist Convention over Critical Race Theory and Christian Nationalism). Because of the critical role of courts in recent political contests and movements, it represents an ideal institutional site to observe religion's relationship to polarization.

\section{Micro-Level}

Sociologists are also uniquely poised to observe polarization at the micro or interactional level through a variety of means. Baldassarri \& coauthors (Baldassari \& Bearman 2008, Baldassarri \& Park 2018, see also Liu \& Srivastava 2015) recognize that partisan sorting and ideological influence are shaped by social homophily and interaction. This has also been informed by research on cultural transformation processes discussed earlier (Vaisey \& Lizardo 2010). For a large portion of Americans across the racial divide, a central context for forging and reinforcing connections between partisan identification, political ideology, and religious identity are in religious institutions such as congregations and schools. Numerous studies have documented the polarization of religious clergy and their influence in shaping their congregants' political attitudes and behaviors (e.g., Boussalis et al. 2021, Djupe \& Gilbert 2003, Uecker \& Lucke 2011). But this influence need not necessarily happen in a top-down fashion. Bean (2014) documents how specific religious practices such as prayer or casual conversations signal partisan expectations and come to define a religious space as inhabited by members of particular political tribe. In a less explored context, Guhin (2020) observes how evangelical private schools in New York City intentionally socialized their students with "culture war" conceptions of global persecution and Islamic threat.

Other qualitative research documents how political engagement itself reacts back on the religious lives and identities of participants. For example, studies (Munson 2008, Wood \& Fulton 2015) have shown that persons who identify as "activists" for religious causes (e.g., antiabortion, racial equity) are often not drawn to that activism because they were deeply religious, but often initially participated in activism because of their friendship networks. Over time, they redefined themselves and their work in activistic and religious terms. This is consistent with 
survey research affirming that partisanship can shape religious identities and behavior (Hout \& Fischer 2002, 2041, Margolis 2018, Patrikios 2008).

Lastly, a whole world of research possibilities open with the development of computational and "big data" tools within the social sciences (Bail 2021). Important research is already being conducted on the links between religious networks online and the dissemination of partisan messages and misinformation. In her landmark study of digital activism, Schradie (2019) documents how well-funded conservative activists in North Carolina, often motivated by a mixture of free market and Christian nationalist ideals, effectively dominated misinformation campaigns on social media, helping to tilt the swing state toward Republicans. Similarly, Guntuku et al. (2021) analyzed 78 million vaccine-related Tweets from December 1, 2020 to February 28, 2021 finding that Tweets coming from counties with larger evangelical populations were more likely to contain anti-vaccine conspiracy theories. But evangelicals could also be a foil to further polarize the electorate on the Left. For example, Freelon \& Lokot (2020) analyzed nearly a decade of activity from Russian social media trolls and found liberals were often spammed with strategic Tweets about the travesties of Trump, Republicans, and evangelical Christians. These few examples underscore the tremendous potential for sociologists to intervene in discussions about religion and growing polarization in innovative ways.

\section{CONCLUSION}

Sociologists must not fall prey to exaggerating the extent of American polarization, particularly when it comes to Americans' social attitudes, which are liberalizing and converging on many issues (Baldassari \& Park 2020, Hout 2021). Nonetheless, political elites are moving toward extremes, the American public is increasingly sorted along partisan and ideological lines, and Americans increasingly distrust one another and democracy. Always in combination with other social factors like race and class, religious identities, beliefs, behaviors, and institutions are deeply implicated in these growing divides.

Sociologists have an opportunity to contribute novel insights to understanding increasing polarization by making religion a more central focus in their discussions. I have surveyed several burgeoning literatures that highlight religion's role in cultural transformation; national identity and politics; intersections between religion, race, and class; and polarizing epistemological 
conflicts. I have also proposed an agenda for theoretical development beyond traditional surveybased research dominated by political scientists.

Importantly, sociologists need not be "sociologists of religion" to give greater primacy to religion within these discussions. As Guhin (2014, see also Brubaker 2015) reminds us, "religion" need not be a sui generis category of behavior, set apart as unique, or a "variable" that is the cause or consequence of some changing political dynamic. Religion can simply be a "site" to observe complex social behavior. To the extent that American politics has become increasingly characterized by "political sectarianism" (Finkel et al. 2020), analyzing changing religious identities and groups can also provide exportable theory with which to understand changing political dynamics. 


\section{REFERENCES:}

Abramowitz AI. 2010. The Disappearing Center: Engaged Citizens, Polarization, and American Democracy. New Haven, CT: Yale Univ. Press

Abramowitz AI, McCoy J. 2018. United States: racial resentment, negative partisanship, and polarization in Trump's America. The ANNALS of the American Academy of Political and Social Science 681(1):137-156

Abramowitz AI, Saunders KL. 2008. Is polarization a myth? Journal of Politics 70(2):542-555.

Alba R, Foner N. 2017. Immigration and the geography of polarization. City \& Community 16(3):239-243

Alwin DF, Tufis PA. 2016. The changing dynamics of class and culture in American politics: a test of the polarization hypothesis. The ANNALS of the American Academy of Political and Social Science 663(1):229-269

American Political Science Association. 1950. Toward a More Responsible Two-Party System. New York: Rinehart

Arbatli E, Rosenberg, D. 2021. United we stand, divided we rule: how political polarization erodes democracy. Democratization 28(2):285-307

Bail C. 2021. Breaking the Social Media Prism: How to Make Our Platforms Less Polarizing. Princeton, NJ: Princeton Univ. Press

Baker JO, Marti G. 2020. Is the religious left resurgent? Sociology of Religion 81(2):131-141

Baker JO, Perry SL, Whitehead AL. 2020a. Keep America Christian (and white): Christian nationalism, fear of ethnoracial outsiders, and intention to vote for Donald Trump in the 2020 presidential election. Sociology of Religion 81(3): 272-293

Baker JO, Perry SL, Whitehead AL. 2020b. Crusading for moral authority: Christian nationalism and opposition to science. Sociological Forum 35(3): 587-607

Baldassarri D, Bearman P. 2007. Dynamics of political polarization. American Sociological Review 72(5):784-811

Baldassarri D, Gelman G. 2008. Partisans without constraint: political polarization and trends in American public opinion. American Journal of Sociology 114:408-46

Baldassarri D, Park B. 2020. Was there ever a culture war? partisan polarization and secular trends in US public opinion. Journal of Politics 82(3):809-827

Bean L. 2014. The Politics of Evangelical Identity: Local Churches and Partisan Divides in the 
United States and Canada. Princeton, NJ: Princeton Univ. Press

Bellah RN. Civil religion in America. Daedalus 96(1):1-21

Bolzendahl C, Coffe H. 2013. Are 'good' citizens 'good' participants? testing citizenship norms and political polarization across 25 nations. Political Studies 61:45-65

Bonikowski B, DiMaggio P. 2016. Varieties of American popular nationalism. American Sociological Review 81:949-980

Bonikowski B, Feinstein Y, Bock S. 2019. The partisan sorting of 'America': how nationalist cleavages shaped the 2016 U.S. presidential election. DOI: $\underline{10.31235 / \mathrm{osf} . i o / p m g 95}$

Boussalis C, Coan TG, Holman MR. 2021. Political speech in religious sermons. Politics and Religion 14(2):241-268

Braunstein R. 2018. A (more) perfect union? religion, politics, and competing stories of America. Sociology of Religion 79(2):172-195

Braunstein R. 2021. The "right" history: religion, race, and nostalgic stories of Christian America. Religions. 12(2): 95 https://doi.org/10.3390/rel12020095

Braunstein R, Fuist TN, Williams RH. (eds.) 2017. Religion and Progressive Activism: New Stories about Faith and Politics. New York: NYU Press

Braunstein R, Taylor M. 2017. Is the tea party a 'religious' movement? religiosity in the tea party versus the religious right. Sociology of Religion 78(1):33-59

Brewer MB, Pierce KP. 2005. Social identity complexity and outgroup tolerance. Personality and Social Psychology Bulletin 31(3):428-437

Brooks C, Manza J. 2004. A great divide? religion and political change in U.S. national elections, 1972-2000. Sociological Quarterly 45(3):421-450

Brooks C, Manza J. 2013. A broken public? Americans' responses to the great recession. American Sociological Review 78(5):727-748

Brubaker R. 2015. Religious dimensions of political conflict and violence. Sociological Theory 33(1):1-19

Burge RP. 2021. The Nones: Where They Came From, Who They Are, and Where They Are Going. Minneapolis, MN: Fortress Press

Burke K, MillerMacPhee A. 2021. Constructing pornography addiction's harms in science, news media, and politics. Social Forces 99(3):1334-1362 
Campbell DE, Layman, GC, Green JC. 2021. Secular surge: a new fault line in American politics. Cambridge, UK: Cambridge Univ. Press

Castle JJ, Stepp KK. 2021. Partisanship, religion, and issue polarization in the United States: a reassessment. Political Behavior 43:1311-1335

Claassen RL, Djupe PA, Lewis AR, Neiheisel JR. 2021. Which party represents my group? the group foundations of partisan choice and polarization. Political Behavior 43:615-636

Cofnas N, Carl N, Woodley of Menie MA. 2018. Does activism in social science explain conservatives' distrust of scientists? The American Sociologist 49: 135-148

Converse PE. 1964. The nature of belief systems in mass publics. In David E. Apter, ed., Ideology and Its Discontents. New York: Free Press of Glencoe, 206-61

Davis NT. 2018. Religion and partisan-ideological sorting, 1984-2016. Social Science Quarterly 99(4):1446-1466

Davis JT. 2019. Funding god's policies, defending whiteness: Christian nationalism and whites' attitudes towards racially-coded government spending. Ethnic and Racial Studies 42(12):2123-2142

Davis JT, Perry SL. 2021. White Christian nationalism and relative political tolerance for racists. Social Problems 68(3):513-534

Davis NJ, Robinson RV. 1996. Are the rumors of war exaggerated? religious orthodoxy and moral progressivism in American. American Journal of Sociology 102(3):757-787

Delehanty J, Edgell P, Stewart E. 2018. Christian America? Secularized evangelical discourse and the boundaries of national belonging. Social Forces 97(3):1283-1306

DellaPosta D, Shi Y, Macy M. 2015. Why do liberals drink lattes? American Journal of Sociology 120(5):1473-1511

DiMaggio P, Evans JH, Bryson B. 1996. Have American's social attitudes become more polarized? American Journal of Sociology 102:690-755

Djupe PA, Gilbert CP. 2003. The Prophetic Pulpit: Clergy, Churches, and Communities in American Politics. Lanham, MD: Rowman \& Littlefield

Du Bois WEB. 1990 (1903). The Souls of Black Folk. New York: Vintage

Edgell P. 2017. An agenda for research on American religion in light of the 2016 election. Sociology of Religion 78(1): 1-8

Edgell P, Tranby E. 2007. Religious influences on understandings of racial inequality in the 
United States. Social Problems 54(2):263-288

Edgell P, Tranby E. 2010. Shared visions? diversity and cultural membership in American life. Social Problems 57(2):175-204

Emerson MO, Smith C. 2000. Divided by faith: evangelical religion and the problem of race in America. New York: Oxford Univ. Press

Evans JH. 2003. Have Americans' attitudes become more polarized? an update. Social Science Quarterly 84:71-90

Evans JH. 2013. The growing social and moral conflict between conservative Protestantism and science. Journal for the Scientific Study of Religion 52(2): 368-385

Evans JH, Hargittai E. 2020. Who doesn't trust Fauci? the public's belief in the expertise and shared values of scientists in the covid-19 pandemic. Socius https://doi.org/10.1177/2378023120947337

Finkel E, Bail CA, Cikara M, Ditto PH, Iyengar S, Klar S, Mason L, McGrath MC, Nyhan B, Rand DG, Skitka LJ, Tucker JA, Van Bavel JJ, Wang CS, Druckman JN. 2020. Political sectarianism in America. Science 370 (6516):533-536

Fiorina MP, Abrams SJ. 2008. Political polarization in the American public. Annual Review of Political Science 11:563-88

Fiorina MP. 2017. Unstable majorities: polarization, party sorting, and political stalemate. Stanford, CA: Hoover Institute Press

Fischer CS, Mattson G. 2009. Is America fragmenting? Annual Review of Sociology 35:435-55

Freelon D, Lokot T. 2020. Russian twitter disinformation campaigns reach across the American political spectrum. The Harvard Kennedy School Misinformation Review http://nrs.harvard.edu/urn-3:HUL.InstRepos:42401973

Froese P, Mencken FC. 2009. A U.S. holy war? the effects of religion on Iraq war policy attitudes. Social Science Quarterly 90(1):103-116

Gauchat G. 2012. Politicization of science in the public sphere: a study of public trust in the United States, 1974 to 2010. American Sociological Review 77(2): 167-187

Gauchat G. 2015. The political context of science in the United States: public acceptance of evidence-based policy and science funding. Social Forces 94(2): 723-746

Gidron N, Bonikowski B. 2013. Varieties of populism: literature review and research agenda. Working Paper no. 13-0004. Cambridge, Mass.: Harvard Univ., Weatherhead Center for International Affairs 
Gorski PS. 2017. American Covenant: A History of Civil Religion from the Puritans to the Present. Princeton, NJ: Princeton Univ. Press

Gorski PS, Perry SL. 2022. The Flag and the Cross: White Christian Nationalism and the Threat to American Democracy. New York: Oxford Univ. Press

Grzymala-Buss A. 2012. Why comparative politics should take religion (more) seriously. Annual Review of Political Science 15:421-442

Guhin J. 2014. Religion as site rather than religion as category: on the sociology of religion's export problem. Sociology of Religion 75(4):579-593

Guhin J. 2020. Agents of God: Boundaries and Authority in Muslim and Christian Schools. New York: Oxford Univ. Press

Gullickson A. 2018. The diverging beliefs and practices of the religiously affiliated and unaffiliated in the United States. Sociological Science 5:361-379

Guntuku SC, Buttenheim AM, Sherman G, Merchant RM. 2021. Twitter discourse reveals geographical and temporal variation in concerns about covid-19 vaccines in the United States. Vaccine 39(30):4034-4038

Hahl O, Kim M, Zuckerman Sivan EW. 2018. The authentic appeal of the lying demagogue: proclaiming the deeper truth about political illegitimacy. American Sociological Review 83(1):1-33

Hasen RL. 2019. Polarization and the judiciary. Annual Review of Political Science 22:261-267

Herberg W. 1955. Protestant, Catholic, Jew: An Essay in American Religious Sociology. Chicago, IL: Univ. of Chicago Press

Hetherington MJ. 2008. Turned off or turned on? how polarization affects political engagement. In Red and Blue Nation?: Consequences and Correction of America's Polarized Politics (pgs 1-53), edited by Pietro S. Nivola and David W. Brady. Stanford, CA: Hoover Institute; Washington, DC: Brookings Institute

Hoffmann JP, Miller AS. 1997. Social and political attitudes among religious groups: convergence and divergence over time. Journal for the Scientific Study of Religion 36(1):52-70

Hoffmann JP, Miller AS. 1998. Denominational influences on socially divisive issues: polarization or continuity? Journal for the Scientific Study of Religion 37(3):528-546

Hout M. 2021. America's liberal social climate and trends: change in 283 general social survey 
variables between and within U.S. birth cohorts, 1972-2018. Public Opinion Quarterly (forthcoming)

Hout M, Fischer CS. 2002. Why more Americans have no religious preference: politics and generations. American Sociological Review 67(2):165-190

Hout M, Fischer CS. 2014. Explaining why more Americans have no religious preference: political backlash and generational succession, 1987-2012. Sociological Science 1:423447

Hout M, Maggio C. 2021. Immigration, race \& political polarization. Daedalus 150(2):40-55

Hunter JD. 1991. Culture Wars. New York: Basic

Hunter JD. 1994. Before the Shooting Begins. New York: The Free Press

Hunter JD. 2000. The Death of Character: Moral Education in an Age without Good or Evil. Basic Books

Inglehart R, Baker WE. 2000. Modernization, cultural change, and the persistence of traditional values. American Sociological Review 65(1):19-51

Iyengar S, Lelkes Y, Levendusky M, Malhotra N, Westwood SJ. 2019. The origins and consequences of affective polarization in the United States. Annual Review of Political Science 22:129-146

Johnson EW, Schwadel P. 2019. Political polarization and long-term change in public support for environmental spending. Social Forces 98(2):913-939

Kiley K, Vaisey S. 2020. Measuring stability and change in personal culture using panel data. American Sociological Review 85(3):477-506

Kozlowski AC. 2021. How conservatives lost confidence in science: the role of ideological alignment in political polarization. Social Forces. DOI: 10.1093/sf/soab020

Layman GC, Carsey TM, Horowitz JM. 2006. Party polarization in American politics: characteristics, causes, and consequences. Annual Review of Political Science 9:83-110

Lee FE. 2015. How Party Polarization Affects Governance. Annual Review of Political Science $18: 261-282$

Lelkes Y. 2016. Mass polarization: manifestations and measurements. Public Opinion Quarterly 80(S1): 392-410

Levendusky MS, Pope JC. 2011. Red states vs. blue states: going beyond the mean. Public Opinion Quarterly 75(2):227-248 
Levitsky S, Ziblatt D. 2018. How Democracies Die. New York: Broadway Books

Lewis AR. 2017. The Rights Turn in Conservative Christian Politics: How Abortion Transformed the Culture Wars. Cambridge, UK: Cambridge Univ. Press

Liu CC, Srivastava SB. 2015. Pulling closer and moving apart: interaction, identity, and influence in the U.S. senate, 1973 to 2009. American Sociological Review 80(1):192-217

Mann M, Schleifer C. 2020. Love the science, hate the scientists: conservative identity protects belief in science and undermines trust in scientists. Social Forces 99(1):305-332

Manza J, Brooks C. 1997. The religious factor in U.S. presidential elections, 1960-1992. American Journal of Sociology 103(1):38-81

Margolis MF. 2018. From Politics to the Pews: How Partisanship and the Political Environment Shape Religious Identity. Chicago: Chicago Univ. Press

Martí G. 2020. American Blindspot: Race, Class, Religion, and the Trump Presidency. Lanham, MD: Rowan \& Littlefield

Mason L. 2015. I disrespectfully agree: the differential effects of partisan sorting on social and issue polarization. American Journal of Political Science 59(1):128-145

Mason L. 2016. A cross-cutting calm: how social sorting drives affective polarization. Public Opinion Quarterly 80:351-377

Mason L. 2018. Uncivil Agreement: How Politics Became Our Identity. Chicago, IL: Univ. of Chicago Press

Mason L, Wronski J. 2018. One tribe to bind them all: how our social group attachments strengthen partisanship. Political Psychology 39:257-277

Mayrl D. 2018. The judicialization of religious freedom: an institutionalist approach. Journal for the Scientific Study of Religion 57(3):514-530

Mayrl D, Venny D. 2021. The dejudicialization of religious freedom? Social Compass. https://doi.org/10.1177/00377686211014725

McCarty N. 2019. Polarization: what everyone needs to know. New York: Oxford Univ. Press

McCright A, Dunlap RE. 2011. The politicization of climate change and polarization in the American public's views of global warming, 2001-2010. Sociological Quarterly 52(2):155-194 
McDaniel EL, Ellison GC. 2008. God's party? race, religion, and partisanship over time. Political Research Quarterly 61(2):180-191

McDaniel EL, Nooruddin I, Shortle AF. 2011. Divine boundaries: how religion shapes citizens' attitudes toward immigrants. American Political Research 39(1):205-233

McVeigh R, Cunningham D, Farrell J. 2014. Political polarization as a social movement outcome: 1960s Klan activism and its enduring impact on political realignment in southern counties, 1960 to 2000. American Sociological Review 79(6):1144-1171

Mummolo J, Nall C. Why partisans do not sort: the constraints on political segregation. Journal of Politics 79(1):45-59

Munson, Z. 2008. The Making of Pro-Life Activists: How Social Movement Mobilization Works. Chicago, IL: Univ. of Chicago Press

Nisbet EC, Cooper KE, Garrett RK. 2015. The partisan brain: how dissonant science messages lead conservatives and liberals to (dis)trust science. The ANNALS of the American Academy of Political and Social Science 658(1):36-66

Noy S, O'Brien TL. 2016. A nation divided: science, religion, and public opinion in the United States. Socius 2: $1-15$

Oberhauser AM, Krier D, Kusow AM. 2019. Political moderation and polarization in the heartland: economics, rurality, and social identity in the 2016 U.S. presidential election. Sociological Quarterly 60(2):224-244

O’Brien J, Abdelhadi E. 2020. Re-examining restructuring: racialization, religious conservatism, and political leanings in contemporary American life. Social Forces 99(2):474-503

O'Brien TL, Noy S. 2015. Traditional, modern, and post-secular perspectives on science and religion in the United States. American Sociological Review 80(1): 92-115

O’Brien TL, Noy S. 2020. Political identity and confidence in science and religion in the United States. Sociology of Religion 81(4): 439-461

Park B. 2018. How are we apart? continuity and change in the structure of ideological disagreement in the American public, 1980-2012. Social Forces 96:1757-84

Patrikios S. 2008. American Republican religion? disentangling the causal link between religion and politics in the United States. Political Behavior 30:367-389

Pearce LD, Gilliland CC. 2020. Religion in America. Berkeley, CA: Univ. of California Press

Perry SL. 2021. Banning because of science or in spite of it? scientific authority, religious 
conservatism, and support for outlawing pornography, 1984-2018. Social Forces. doi: 10.1093/sf/soab024

Perry SL, Baker JO, Grubbs JB. 2021. Ignorance or culture war? Christian nationalism and scientific illiteracy. Public Understanding of Science https://doi.org/10.1177/09636625211006271

Perry SL, Schnabel L, Grubbs JB. 2021. Christian nationalism, perceived anti-Christian discrimination, and prioritizing 'religious freedom' in the 2020 presidential election. Nations and Nationalism. https://doi.org/10.1111/nana.12764

Perry SL, Whitehead AL. 2015. Christian nationalism and white racial boundaries: examining whites' opposition to interracial marriage. Ethnic and Racial Studies 38(10):1671-1689

Perry SL, Whitehead AL. 2019. Christian America in black and white: racial identity, religiousnational group boundaries, and explanations for racial inequality. Sociology of Religion 80(3):277-298

Perry SL, Whitehead AL, Grubbs JB. 2020. Culture wars and covid-19 conduct: Christian nationalism, religiosity, and Americans' behavior during the coronavirus pandemic. Journal for the Scientific Study of Religion 59(3): 405-416

Perry SL, Whitehead AL, Grubbs JB. 2021a. Prejudice and pandemic in the promised land: how white Christian nationalism shapes Americans' racist and xenophobic views of covid-19. Ethnic and Racial Studies 44(5):759-772

Perry SL, Whitehead AL, Grubbs JB. 2021b. Save the economy, liberty, and yourself: Christian nationalism and Americans' views on government covid-19 restrictions. Sociology of Religion. https://doi.org/10.1093/socrel/sraa047

Pierson P, Schickler E. 2020. Madison's constitution under stress: a developmental analysis of political polarization. Annual Review of Political Science 23:37-58

Prior M. 2013. Media and political polarization. Annual Review of Political Science 16:101-127

Rhodes J. 2011. Choosing sides: an exploration of role conflict among evangelical Democrats. Sociology of Religion 72(1):28-49

Schnabel L. 2016. Gender and homosexuality attitudes across religious groups from the 1970s to 2014: similarity, distinction, and adaptation. Social Science Research 55(1):31-47

Schnabel L. 2021. Opiate of the masses? inequality, religion, and political ideology in the United States. Social Forces 99(3):979-1012

Schnabel L, Bock S. 2017. The persistent and exceptional intensity of American religion: a response to recent research. Sociological Science 4:686-700 
Schradie J. 2019. The revolution that wasn't: how digital activism favors conservatives. Cambridge, MA: Harvard Univ. Press

Schwadel P. 2017. The republicanization of evangelical Protestants in the United States: an examination of the sources of political realignment. Social Science Research 62:238-254

Sherkat DE, Lehman D. 2018. Bad Samaritans: religion and anti-immigrant and anti-Muslim sentiment in the United States. Social Science Quarterly 99(5):1791-1804

Smith C. 1998. American Evangelicalism: Embattled and Thriving. Chicago, IL: Univ. of Chicago Press

Stewart E, Edgell P, Delehanty J. 2018. The politics of religious prejudice and tolerance for cultural others. Sociological Quarterly 59(1): 17-39

Uecker JE, Lucke G. 2011. Protestant clergy and culture wars: an empirical test of Hunter's thesis. Journal for the Scientific Study of Religion 50(4):692-706

Vaisey S, Kiley K. 2021. A model-based method for detecting persistent cultural change using panel data. Sociological Science 8:83-95

Vaisey S, Lizardo O. 2010. Can cultural worldviews influence network composition? Social Forces 88(4):1595-1618

Vann B Jr. 2021. Persuasive action and ideological polarization in Congress. Social Problems. DOI: $10.1093 /$ socpro/spab023

Voas D, Chaves M. 2018. Even intense religiosity is declining in the United States. Sociological Science 5:694-710

Vogl TS, Freese J. 2020. Differential fertility makes society more conservative on family values. Proceedings of the National Academy of Science 117(14):7696-7701

Whitehead AL, Perry SL. 2015. A more perfect union? Christian nationalism and support for same-sex unions. Sociological Perspectives 58: 422-440

Whitehead AL, Perry SL. 2020a. Taking America Back for God: Christian Nationalism in the United States. New York: Oxford Univ. Press

Whitehead AL, Perry SL. 2020b. How culture wars delay herd immunity: Christian nationalism and anti-vaccine attitudes. Socius. https://doi.org/10.1177/2378023120977727

Whitehead AL, Perry SL, Baker, JO. 2018. Make America Christian again: Christian nationalism and voting for Donald Trump in 2016 presidential election. Sociology of Religion 79(2): $147-171$ 
Wilde MJ. 2018. Complex religion: interrogating assumptions of independence in the study of religion. Sociology of Religion 79(3):287-298

Wilde MJ, Glassman L. 2016. How complex religion can improve our understanding of American politics. Annual Review of Sociology 42:407-425

Wilde MJ, Tevington P. 2017. Complex religion: toward a better understanding of the ways in which religion intersects with inequality. In Emerging Trends in the Social and Behavioral Sciences: An Interdisciplinary, Searchable, and Linkable Resource, ed. RA Scott, SM Kosslyn. Hoboken, NJ: John Wiley \& Sons

Wood RL, Fulton BR. 2015. A Shared Future: Faith-Based Organizing for Racial Equity and Ethical Democracy. Chicago, IL: Univ. of Chicago Press

Wuthnow R. 1988. The Restructuring of American Religion: Society and Faith Since World War II. Princeton, NJ: Princeton Univ. Press

Wuthnow R. 1989. The Struggle for America's Soul: Evangelicals, Liberals, and Secularism. Grand Rapids, MI: William B. Eerdmans Publishing

Wuthnow R. 2021. Why Religion is Good for American Democracy. Princeton, NJ: Princeton Univ. Press

Yukich G, Edgell P. (eds.) 2020. Religion is Raced: Understanding American Religion in the Twenty-First Century. New York: New York Univ. Press 